\title{
ESTIMATED STEADY-STATE COMPOSITIONS OF SUPERNATANT LIQUID DURING SLUDGE WASHIN!G
}

by D. T. Hobbs

Westinghouse Savannah River Company

Savannah River Site

Aiken, South Carolina 29808

Other Authors:

This paper was prepared in connection with work done under Contract No. DE-AC09-89SR18035 with the U. S. Department of Energy. By acceptance of this paper, the publisher and/or recipient acknowledges the U. S. Gove : ment's right to retain a nonexclusive, royalty-free license in and to any copyright covering this paper, along with the right to reproduce and to authorize others to reproduce all or part of the copyrighted paper.

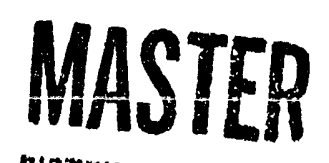




\section{DISCLAIMER}

This report was prepared as an account of work sponsored by an agency of the United States Government. Neither the United States Government nor any agency thereof, nor any of their employees, makes any warranty, express or implied, or assumes any legal liability or responsibility for the accuracy, completeness, or usefulness of any information, apparatus, product, or process disclosed, or represents that its use would not infringe privately owned rights. Reference herein to any specific commercial product, process, or service by trade name, trademark, manufacturer, or otherwise does not necessarily constitute or imply its endorsement, recommendation, or favoring by the United States Government or any agency thereof. The views and opinions of authors expressed herein do not necessarily state or reflect those of the United States Government or any agency thereof.

This report has been reproduced directly from the best available copy.

Available to DOE and DOE contractors from the Office of Scientific and Technical Information, P. O. Box 62, Oak Ridge, TN 37831; prices available from (615) 576-8401.

Available to the public from the National Technical Information Service, U. S. Department of Commerce, 5285 Port Royal Rd., Springfield, VA 22161. 
WESTINGHOUSE SAVANNAH RIVER COMPANY SAVANNAH RIVER LABORATORY

\section{3 \\ WSRC-RP-91-1138}

Keywords: Nitrate, $\mathrm{pH}$, Hydroxide, Carbon dioxide Bicarbonate, Carbonate, Absorption, HLW

November 12, 1991

To:

D. L. F1sh, 773-A

Dit

SRL

From: D. T. Hobbs, 773-A

\section{Estimated Steady-State Compositions of Supernatant Liquid During Sludge washing (U)}

\section{SUMMARY}

Steady-state hydroxide, $\mathrm{pH}$, carbonate and bicarbonate levels have been estimated for supernatant liquids during sludge washing and storage. These compositions were needed in order to prepare synthetic solutions for determining inhibitor requirements. The steady-state $\mathrm{pH}$ was plotted versus the nitrate concentration and fitted to a logarithmic expression of the form,

$$
\mathrm{pH}=10.23 \times\left[\mathrm{NO}_{3}-\right]^{0.0178}
$$

where $\left[\mathrm{NO}_{3}{ }^{-}\right]$is the concentration of nitrate in moles/liter. Similar expressions were also developed for calculating the concentrations of carbonate and bicarbonate as a function of the nitrate concentration.

\section{INTRODOCTION}

During sludge washing and storage, the hydroxide concentration in the supernatant liquid of the sludge can decrease by up to five orders of magnitude due to a combination of dilution and absorption of atmospherlc carbon dioxide. Previous corrosion testing has shown that the supernatant liquid is much more corrosive at the lower hydroxide concentrations (lower pH).1 Nitrite has been found to be an effective corrosion inhibitor at low hydroxide concentrations. ${ }^{2}$ The steady-state concentrations of hydroxide $(\mathrm{pH})$, blcarbonate and carbonate were estimated so that synthetic solutions could be prepared and tested to determine the inhibitor requirements during sludge washing and storage. 


\section{DISCUSSION}

Duxing sludge washlng, the soluble salt concentration in the supernatant liquid will be diluted by a factor of about seventy. ${ }^{3}$ It was assumed that fourteen separate washing steps will be required to reduce the soluble salt concentration to meet the vitrification feed specification. Thus, the soluble salt concentration is diluted by a factor of 1.36 at each washing step.

Air is continuously pulled through the processing tanks to prevent the accumulation of a flammable mixture of hydrogen. Because of the high alkalinity, atmospheric carbon dioxide is absorbed into the supernatant liquid. The absorbed carbon dioxide reacts with hydroxide producing bicarbonate and carbonate species, and reducing the hydroxide concentration and $\mathrm{pH}$.

Carbon dioxide is absorbed until a steady-state condition is reached. Steady-state is reached when the partial pressure of carbon dioxide in equilibrium with the solution containing hydroxide, blcarbonate and carbonate equals the partial pressure of carbon dioxide in the air entering the tank. The steady-state condition depends on the initial hydroxide and the initial carbonate concentration and the atmospheric concentration of carbon dioxide.

Steady-state concentrations of hydroxide, $\mathrm{pH}$ and total carbonate were calculated for each washing step using the previously reported waste tank absorption model. "The composition of the supernatant liquid at the beginning of washing was set at 70.2 times the concentration of that reported for washed sludge. 5 For these calculations, the atmosphertc carbon dioxide concentration was assumed to be a constant $360 \mathrm{ppm}$, which is the average concentration measured over a one year period in 1986 and 1987.6 Blcarbonate and carbonate concentrations were calculated using the reported equilibrium values.?

The estimated steady-state compositions are given in Table I. The steady-state pH ranges from 9.51 to 10.28 . During the first half of washing, carbonate is the predominant carbonate spectes. During the latter half of washing and during storage, bicarbonate is the predominant carbonate species.

Plots of the steady-state $\mathrm{pH}$ and blcarbonate and carbonate concentrations versus the nitrate concentration are given in Figures 1 and 2. Each set of data was fit to a logarithmic expresston. The expressions for $\mathrm{pH}$, carbonate and bicarbonate are given below.

$$
\begin{aligned}
& \mathrm{pH}=10.23 \times\left[\mathrm{NO}_{3}^{-}\right]^{0.0170} \\
& {\left[\mathrm{CO}_{3}{ }^{-2}\right]=0.577 \times\left[\mathrm{NO}_{3}^{-}\right]^{1.22}} \\
& {\left[\mathrm{HCO}_{3}^{-}\right]=0.329 \times\left[\mathrm{NO}_{3}^{-}\right]^{0.690}}
\end{aligned}
$$



D. L. Fish
page $-3-$
WSRC-RP-91-1138

Table I. Estimated steady-State Compositions of Supernatant Liquid During Sludge Washing

\begin{tabular}{|c|c|c|c|c|c|}
\hline $\begin{array}{l}\text { Wash } \\
\text { Step }\end{array}$ & $\begin{array}{l}\text { [Nitrate] } \\
\text { (melar) }\end{array}$ & $\begin{array}{l}\text { (Hydroxidej } \\
\text { (melar) }\end{array}$ & $\mathrm{pH}$ & $\begin{array}{l}{\left[\mathrm{HCO}_{3}{ }^{-}\right]} \\
\text {(molarl }\end{array}$ & $\begin{array}{l}{\left[\mathrm{CO}_{3}^{2-}\right]} \\
\text { (melar) }\end{array}$ \\
\hline 0 & $1.44 \mathrm{E}+0$ & $4.05 E-4$ & 10.28 & $4.09 E-1$ & $8.31 E-1$ \\
\hline 1 & $1.03 E+0$ & $3.46 \mathrm{E}-4$ & 10.22 & $3.32 E-1$ & $5.75 \mathrm{E}-1$ \\
\hline 2 & $7.46 \mathrm{E}-1$ & $2.96 E-4$ & 10.17 & $2.68 E-1$ & $3.98 E-1$ \\
\hline 3 & $5.38 \mathrm{E}-1$ & $2.52 \mathrm{E}-4$ & 10.12 & $2.16 E-1$ & $2.72 \mathrm{E}-1$ \\
\hline 4 & $3.88 \mathrm{E}-1$ & $2.15 E-4$ & 10.06 & $1.73 E-1$ & $1.87 \mathrm{E}-1$ \\
\hline 5 & $2.80 E-1$ & $1.82 E-4$ & 10.01 & 1. $39 \mathrm{E}-1$ & $1.27 \mathrm{E}-1$ \\
\hline 6 & $2.02 E-1$ & 1. $55 \mathrm{E}-4$ & 9.96 & $1.11 \mathrm{E}-1$ & 8. $65 E-2$ \\
\hline 7 & 1. $46 \mathrm{E}-1$ & $1.31 \mathrm{E}-4$ & 9.91 & $8.88 E-2$ & $5.82 \mathrm{E}-2$ \\
\hline 8 & $1.05 \mathrm{E}-1$ & $1.11 \mathrm{E}-4$ & 9.85 & $7.07 \mathrm{E}-2$ & $3.93 \mathrm{E}-2$ \\
\hline 9 & $7.58 \mathrm{E}-2$ & $9.31 \mathrm{E}-5$ & 9.79 & $5.64 \mathrm{E}-2$ & 2. $63 \mathrm{E}-2$ \\
\hline 10 & $5.46 \mathrm{E}-2$ & $7.73 E-5$ & 9.73 & $4.46 E-2$ & $1.73 \mathrm{E}-2$ \\
\hline 11 & $3.94 \mathrm{E}-2$ & $6.36 \mathrm{E}-5$ & 9.66 & $3.53 E-2$ & $1.12 \mathrm{E}-2$ \\
\hline 12 & $2.84 \mathrm{E}-2$ & $5.20 \mathrm{E}-5$ & 9.59 & $2.78 E-2$ & $7.25 E-3$ \\
\hline 13 & $2.05 \mathrm{E}-2$ & $4.18 \mathrm{E}-5$ & 9.51 & $2.17 \mathrm{E}-2$ & $4.55 E-3$ \\
\hline
\end{tabular}


D. L. Fish page $-4-$ WSRC-RP-91-1138

Figure 1. Estimated Steady-State pH of the Supernatant Liquid During sludge Washing

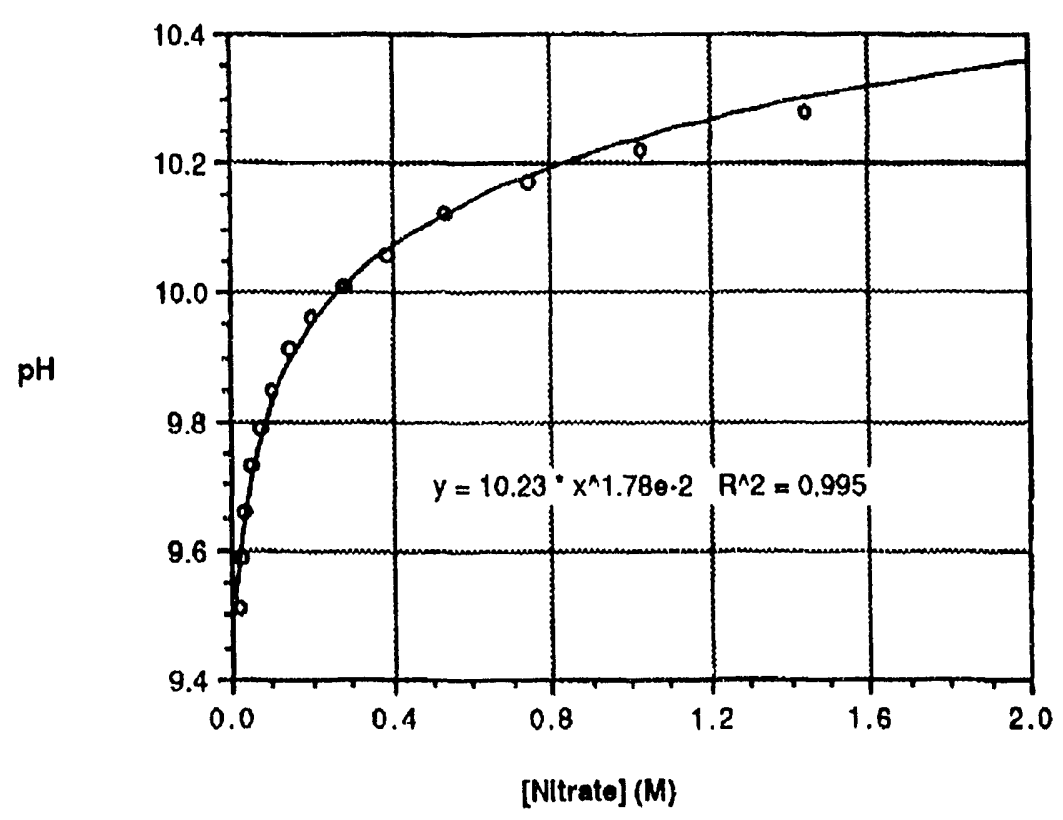



D. L. Fish
page -5
WSRC-RP $-91-1138$

Figure 2. Estimated steady-state Bicarbonate and Caxbonate Concentrations in the Supernatant Iiquid During sludge Washing

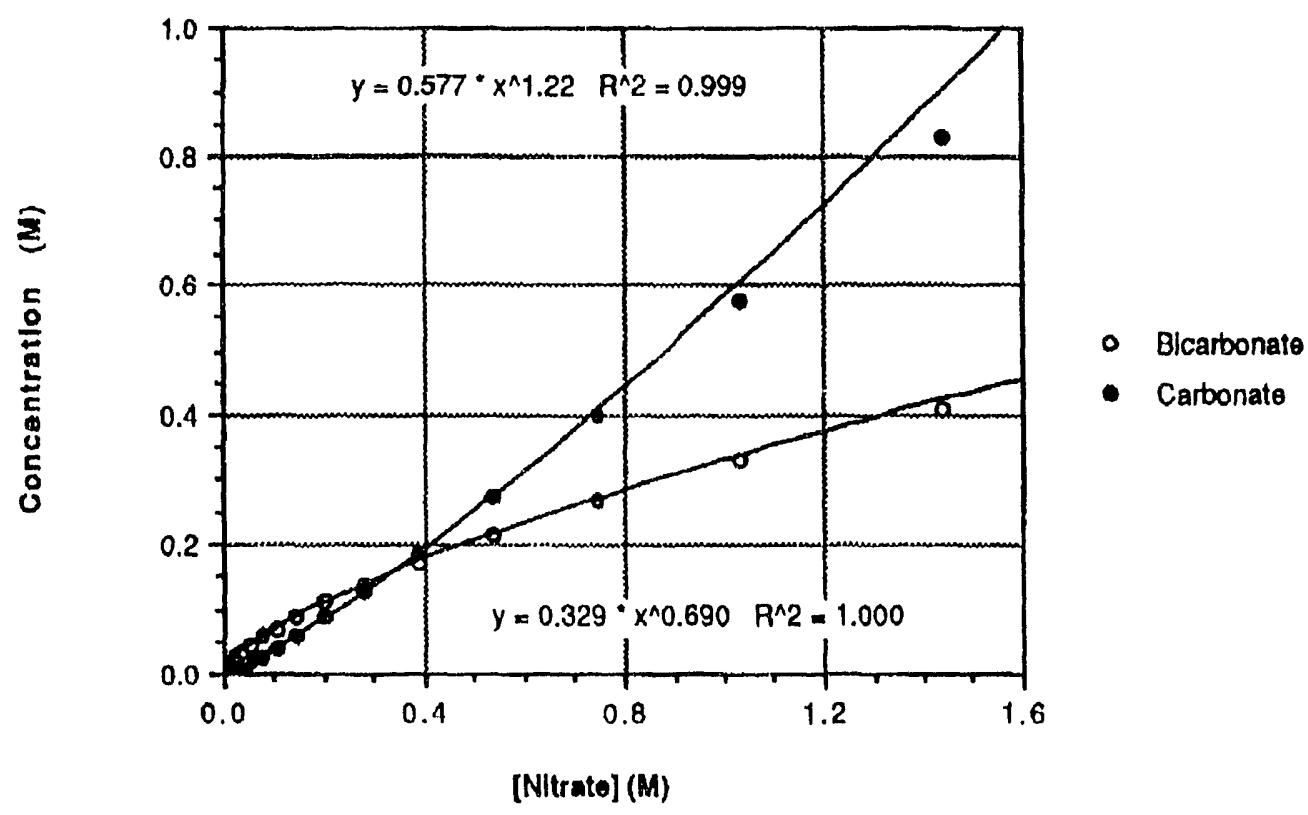

\section{REEERENCES}

1. A. F. Riechman, "In-Tank Processing: Corrosion Phenomena Due to Storage of Dilute Waste Solutions", DPST-86-236, January 20, 1986.

2. J. W. Congdon and J. S. Lozier, "Inhibition of washed Sludge with Sodium Nitrite", DEST-87-379, April 7, 1987.

3. T. Motyka, "Technical Data Summary for In-Tank Sludge Processing", DPSTD-84-100, Aprt1, 1984.

4. D. T. Hobbs and R. M. Wallace, "Hydroxide Depletion in Waste Storage Tanks BY Reaction With Carbon Dioxide", DPST-85-846, October 14, 1985.

5. "Basic Data Report -- Defense Waste Processing Eacility - Sludge Plant", DPSP-80-1033, Appendix G, Rev. 90, October 30, 1984.

6. D. T. Hobbs, "Absorption of Carbon Dioxide in Waste Tanks", DPST-87-596, september 3, 1987.

7. "Lange's Handbook of Chemistry", J. A. Dean, editor, McGraw-Hill, New York, 13th edition, 1985. 

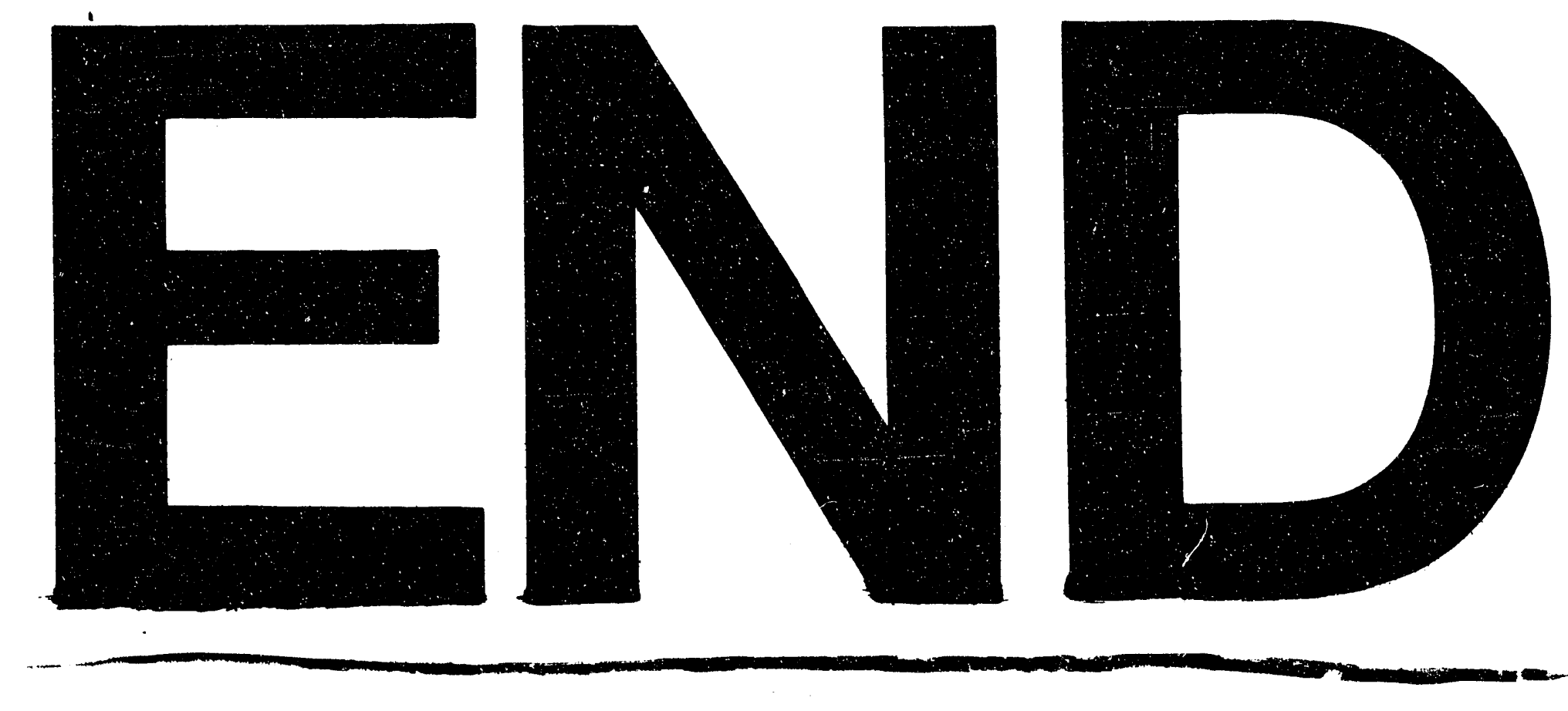
